\title{
Analytical Study of a Modified Thermal Energy Storage System for PS10 in Aswan
}

\author{
M. Qenawy *1, S. Abdelhady ${ }^{2}$ \\ Mechanical Power Engineering Department, \\ Aswan University, Aswan, Egypt \\ *m_qenawy@ymail.com
}

\begin{abstract}
According to the need to a renewable energy source for electric power generation to fit the required loud curve in the isolated Toshka area near Aswan, it is proposed to install a similar power plant as PS10 of Spain with a modified storage system. PS10 is a commercial CSP of 11MW power that has available analysis in literature. In this study, we compare the performance of the PS10 with a modified storage system when operated in Spain and its performance with the same storage system when operated in Aswan. The introduced storage system has two tanks of suitable molten salts. Such solution is found very promising to accommodate the life in arid zones in Aswan for the whole day-hours. The comparison shows also valuable advantages of selecting Aswan to operate such system in comparison to Spain
\end{abstract}

Keywords: Solar Power Tower System, CSP, Thermal Energy Storage, Modified Thermal Energy Storage

\section{INTRODUCTION}

Thermal Energy Storage works to make concentrated solar tower (CST) a more flexible and valuable technology for electricity generation. Thermal Energy Storage makes CST possible to meet electricity peak demand not only by extending the operation time when there is no solar irradiation but also by overcoming weather fluctuations. PS10 is a concentrating solar thermal power plant of $11 \mathrm{MW}$ output power $11 \mathrm{MW}$. It is based on tower technology for gridconnected electricity generation [1, 2, 3, 4, and 5]. PS10 plant is located in the town of Sanlúcar la Mayor $37.2^{\circ}$ Latitude, 25 $\mathrm{km}$ west from the city of Seville. PS10 plant is working with Direct Saturated steam Generation (DSG) concept, at considerably low temperatures $\left(250^{\circ} \mathrm{C}-270^{\circ} \mathrm{C}\right)$, at a pressure of $40 \mathrm{bar}$. The annual energy generation amounts to $23 \mathrm{GWh}$ as presented in Figure (1) $[6,7]$.

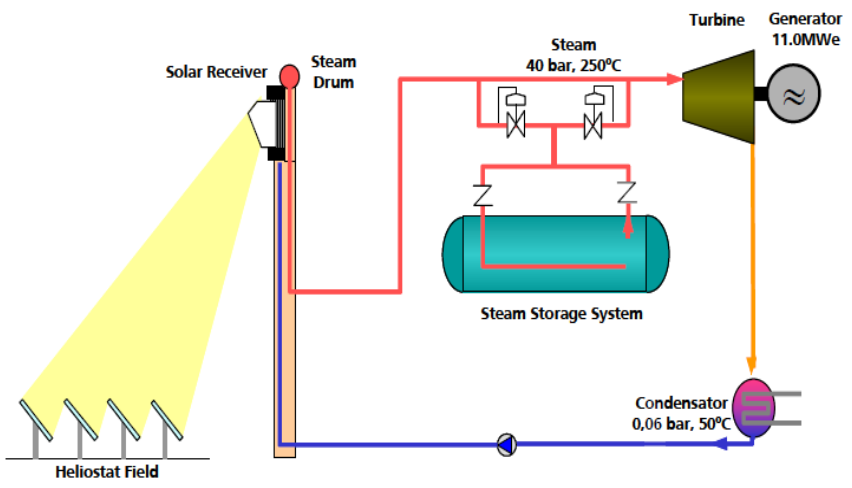

Figure (1) PS10 in Sanlúcar la Mayor, Spain
MPS10 plant is a PS10 plant with two tank molten salt thermal energy storage. In a molten-salt solar power tower, liquid salt at $290^{\circ} \mathrm{C}$ (minimum operation temperature) is pumped from a 'cold' storage tank through the receiver where it is heated to $565^{\circ} \mathrm{C}$ (maximum operation temperature) [8, 9, 10 , and 11] and then on to a 'hot' tank for storage. When power is needed from the plant, hot salt is pumped to a steam generating system that produces superheated steam for a conventional Rankine cycle turbine/generator system. From the steam generator, the salt is returned to the cold tank where it is stored and eventually reheated in the receiver $[12,13]$. The molten salt is a nitrate salt consisted by $\left(60 \% \mathrm{NaNO}_{3}\right.$, $\left.40 \% \mathrm{KNO}_{3}\right)$ with a specific heat $(\mathrm{Cp})$ equal to $(2660 \mathrm{~J} / \mathrm{Kg} \cdot \mathrm{K}$.) and a density of $(1870 \mathrm{~kg} / \mathrm{m} 3)$ at $\left(565^{\circ} \mathrm{C}\right)$. These values will be considered constant during the calculations for different operating temperatures [4, 14]. Figure (2) is a schematic diagram of the primary flow paths in a two tank molten-salt solar power plant.

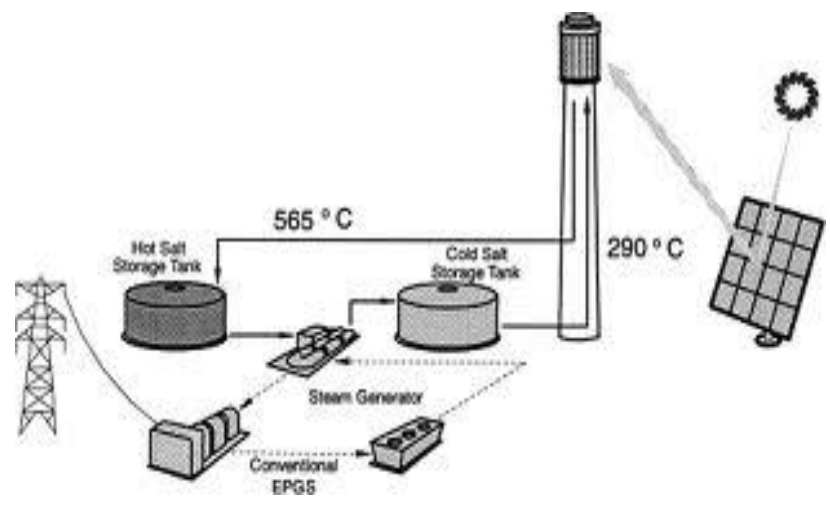

Figure (2) two tank molten salt solar power plant 


\section{STORAGE SYSTEM}

It's possible to design the storage system, consisted by hot tank and cold tank and using dynamic differential equations for the heat transfer between the fluid and each tank, with energy balances on the cold and the hot tanks. The followed criteria to design the storage system are based on the autonomy of the CSP plant, where the goal is to achieve many hours of electrical power production per day without solar radiation. First of all it's assumed that the system doesn't have any losses ( $\mathrm{U}=0.0$; adiabatic operation) i.e. Outlet tower temperature $\left(\mathrm{T}_{\mathrm{tr}, \mathrm{o}}\right)$ is equal to the hot tank outlet temperature $\left(\mathrm{T}_{\mathrm{h}, \mathrm{o}}=565^{\circ} \mathrm{C}\right)$, and the outlet temperature of heat exchanger at steam generator block $\left(\mathrm{T}_{\text {tur, }}{ }_{\mathrm{o}}\right)$ is equal to the outlet temperature of the cold tank $\left(\mathrm{T}_{\mathrm{c}, \mathrm{o}}=290^{\circ} \mathrm{C}\right)[4]$. Second point in this work was the mass flow rate of molten salt to heat exchanger of power block ( $\left.\dot{\mathrm{m}}_{\text {tur }}\right)$ is constant along the turbine operation. But the flow rate of molten salt to the tower $\left(\dot{\mathrm{m}}_{\mathrm{tr}}\right)$ is varying to remains the outlet tower temperature $\left(\mathrm{T}_{\mathrm{tr}, \mathrm{o}}\right)$ constant at $\left(565^{\circ} \mathrm{C}\right)$ by using a control on the pumping system of the tower. The energy balance equations applied to the MPS10 storage plant as the following [2, 4, 15 and 16].

\subsection{Tower}

The formula which describes the tower receiver operation can be expressed as follows [4]:

$$
\eta_{\mathrm{tr}}=\frac{\dot{\mathrm{m}}_{\mathrm{tr}} \mathrm{Cp}\left(\mathrm{T}_{\mathrm{tr}, \mathrm{o}}-\mathrm{T}_{\mathrm{tr}, \mathrm{in}}\right)}{\mathrm{Q}_{\mathrm{tr}}}
$$

\subsection{The Hot storage tank}

The following equations-set describes the energy and mass balance of the hot storage tank $[4,15]$ :

$$
\begin{aligned}
& \frac{\mathrm{dM}}{\mathrm{dt}}=\dot{\mathrm{m}}_{\mathrm{tr}}-\dot{\mathrm{m}}_{\mathrm{tur}} \\
& \frac{\mathrm{dE}}{\mathrm{dt}}=\dot{\mathrm{m}}_{\mathrm{tr}} \mathrm{Cp}_{\mathrm{h}, \mathrm{in}}-\dot{\mathrm{m}}_{\mathrm{tur}} \mathrm{Cp} \mathrm{T}_{\mathrm{h}, \mathrm{o}} \\
& \frac{\mathrm{dE}}{\mathrm{dt}}=\left(\dot{\mathrm{m}}_{\mathrm{tr}}-\dot{\mathrm{m}}_{\mathrm{tur}}\right) \mathrm{Cp} \mathrm{T}_{\mathrm{h}, \mathrm{o}}+\mathrm{M} \mathrm{Cp} \frac{\mathrm{dT}_{\mathrm{h}_{\mathrm{h}} \mathrm{o}}}{\mathrm{dt}}
\end{aligned}
$$

\subsection{The Steam generator}

The following equation expresses the steam generation in the boiler [4, 17]:

$$
\mathrm{Q}_{\mathrm{gg}}=\dot{\mathrm{m}}_{\mathrm{tur}} \mathrm{Cp}\left(\mathrm{T}_{\text {tur,in }}-\mathrm{T}_{\text {tur }, \mathrm{o}}\right)
$$

\subsection{The Cold storage tank}

The following equations-set describes the energy and mass balance of the cold storage tank which is similar to the hot tank in those equations $[4,15]$ :

$$
\frac{\mathrm{dM}}{\mathrm{dt}}=\dot{\mathrm{m}}_{\mathrm{tur}}-\dot{\mathrm{m}}_{\mathrm{tr}}
$$

$$
\begin{aligned}
& \frac{\mathrm{dE}}{\mathrm{dt}}=\dot{\mathrm{m}}_{\mathrm{tur}} \mathrm{Cp} \mathrm{T}_{\mathrm{c}, \mathrm{in}}-\dot{\mathrm{m}}_{\mathrm{tr}} \mathrm{Cp} \mathrm{T}_{\mathrm{c}, \mathrm{O}} \\
& \frac{\mathrm{dE}}{\mathrm{dt}}=\left(\dot{\mathrm{m}}_{\mathrm{tur}}-\dot{\mathrm{m}}_{\mathrm{tr}}\right) \mathrm{Cp} \mathrm{T}_{\mathrm{c}, \mathrm{O}}+\mathrm{MCp} \frac{\mathrm{dT}_{\mathrm{c}, \mathrm{O}}}{\mathrm{dt}}
\end{aligned}
$$

\section{RESULTS}

The electrical power for PS10 is $11 \mathrm{MWe}$ that required $30.17 \mathrm{MWe}$ at the tower receiver. If this power is constant during the daylight hours (11 hours average for Spain) this means that the capacity factor is $45.8 \%$ and this can show clearly by the simulation results on the MATLAB program. Figure (3) shows the outlet temperature of the hot tank and the outlet temperature of the power block. Figure (4) shows the behaviour of mass of the hot and the cold tank the first days of plant operation.

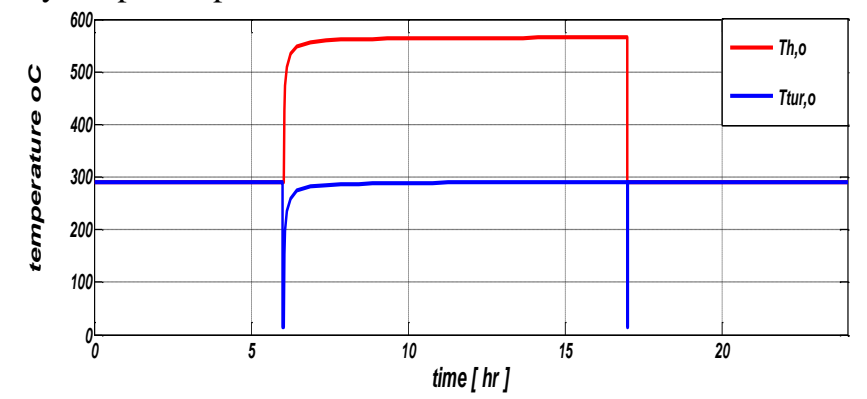

Figure (3) Simulation results of outlet temperature of the hot tank and the outlet temperature of the power block

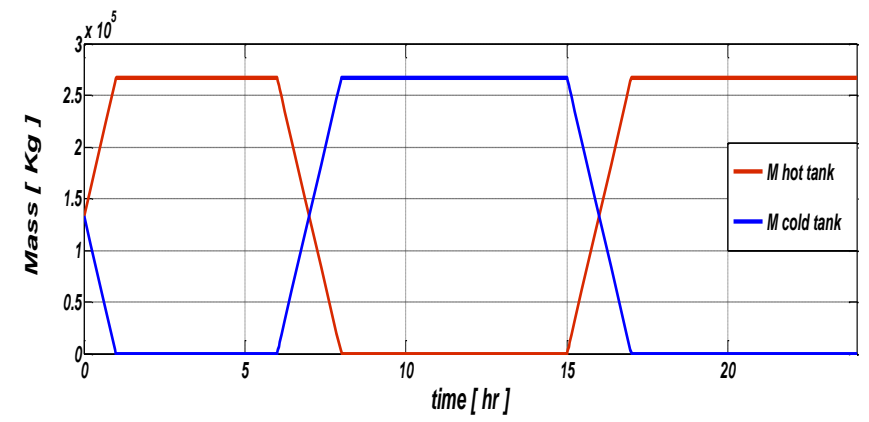

Figure (4) Simulation results of the mass of the cold and hot tank at the first day of plant operation

Now we should consider the actual condition of solar flux along the days of the year for MPS10 plant in Spain and Egypt. In this analysis via an Excel sheet we take $21^{\text {th }}$ March as a reference day for plant operation.

\subsection{Results of MPS10 in Spain}

MPS10 plant in Spain with total optical efficiency of $66.74 \%$ [13] required (400Ton) of molten salt besides two storage tanks of dimensions $\left(213.9 \mathrm{~m}^{3}, 4 \mathrm{~m}\right.$ height, and $8.25 \mathrm{~m}$ diameter). This increases the capacity factor of the plant to (0.375) i.e. 90MWh during the day. Figure (5) show solar and plant power during $21^{\text {th }}, 22^{\text {th }}$ march. Figure (6) show the mass of hot and cold tanks during the beginning of operation and figure (7) show the next two days. 


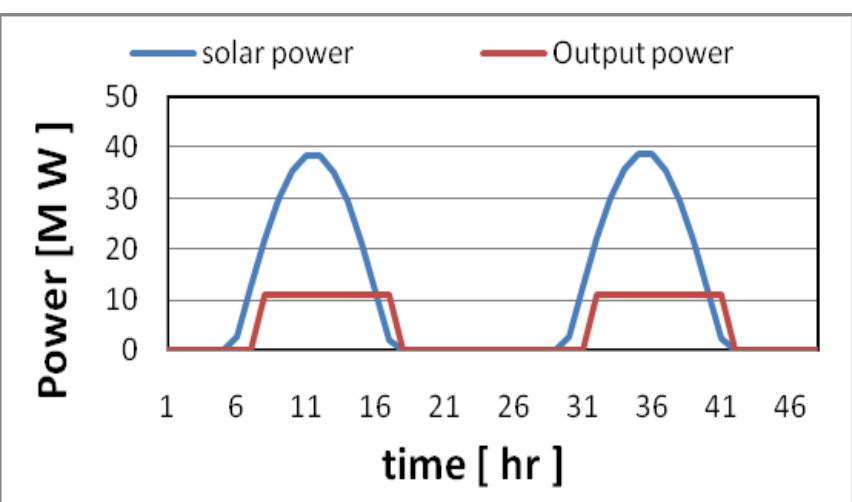

Figure (5) The solar and plant power during $21^{\text {th }}, 22^{\text {th }}$ march for MPS10 in Spain $(37.5 \%$ capacity factor $)$

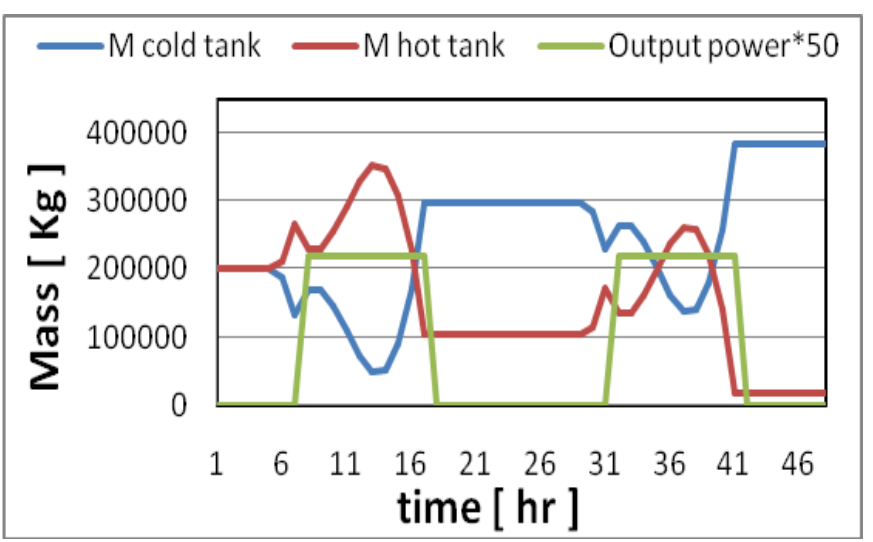

Figure (6) The behaviour of mass of hot and cold tanks and the electrical power generation during $21^{\text {th }}, 22^{\text {th }}$ march for MPS10 in Spain (37.5\% capacity factor)

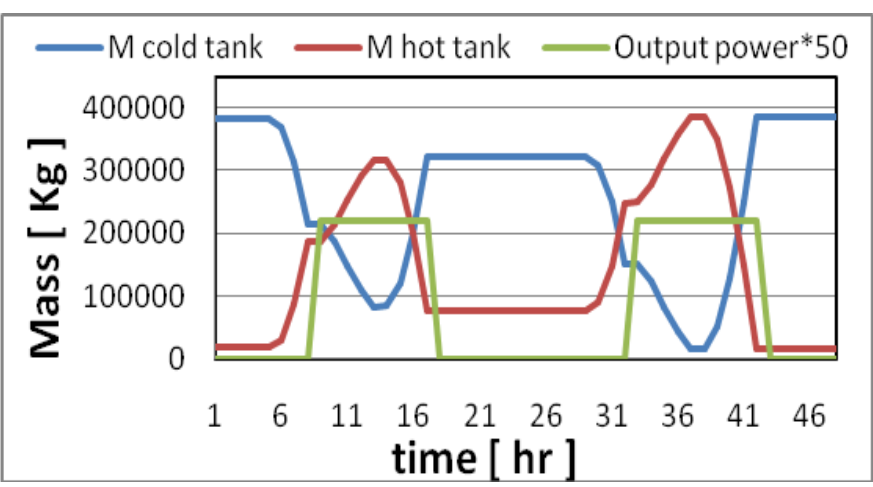

Figure (7) The behaviour of mass of hot and cold tank and the electrical power generation during $23^{\text {th }}, 24^{\text {th }}$ march for MPS10 in Spain

$$
\text { (37.5\% capacity factor) }
$$

\subsection{Results of MPS10 in Egypt}

MPS10 plant in Aswan with total optical efficiency of $67.47 \%$ [13] required (560Ton) of molten salt besides two storage tanks of dimensions $\left(299.5 \mathrm{~m}^{3}, 4 \mathrm{~m}\right.$ height, and $9.76 \mathrm{~m}$ diameter). This increases the capacity factor of the plant to (0.458) i.e. $110 \mathrm{MWh}$ during the day. Figure (8) show solar and plant power during $21^{\text {th }}, 22^{\text {th }}$ march. Figure (9) show the mass of hot and cold tank during the beginning of operation and figure (10) show the next two days.

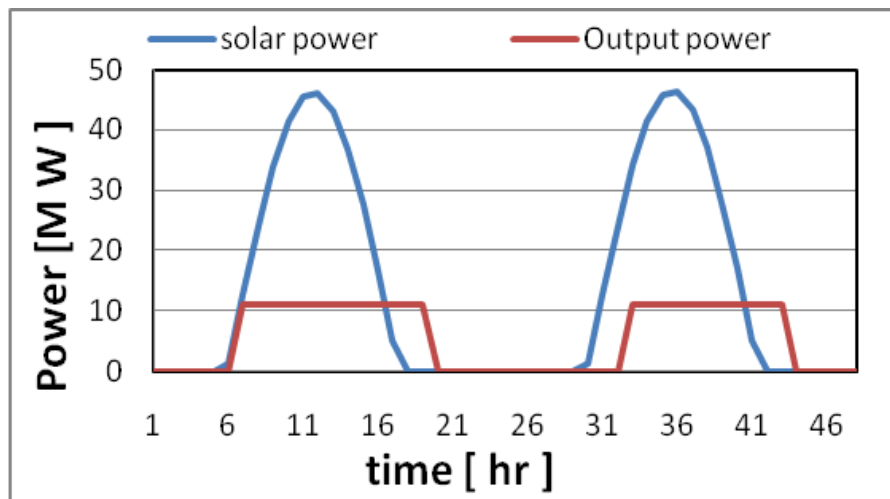

Figure (8) The solar and plant power during $21^{\text {th }}, 22^{t_{\mathrm{h}}}$ march for MPS10 in Aswan (45.8\% capacity factor)

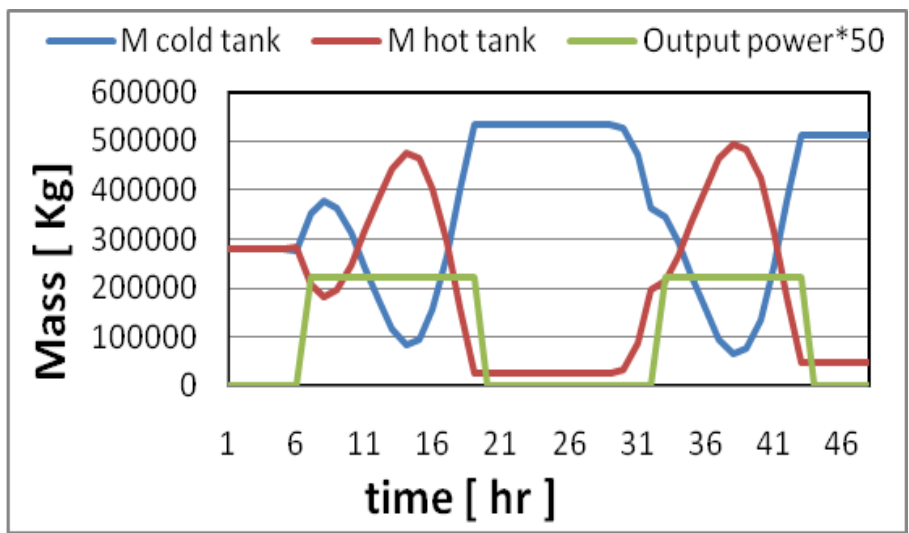

Figure (9) the behaviour of mass of hot and cold tank and the electrical power generation during $21^{\text {th }}, 22^{\text {th }}$ march for MPS10 in Aswan ( $45.8 \%$ capacity factor)

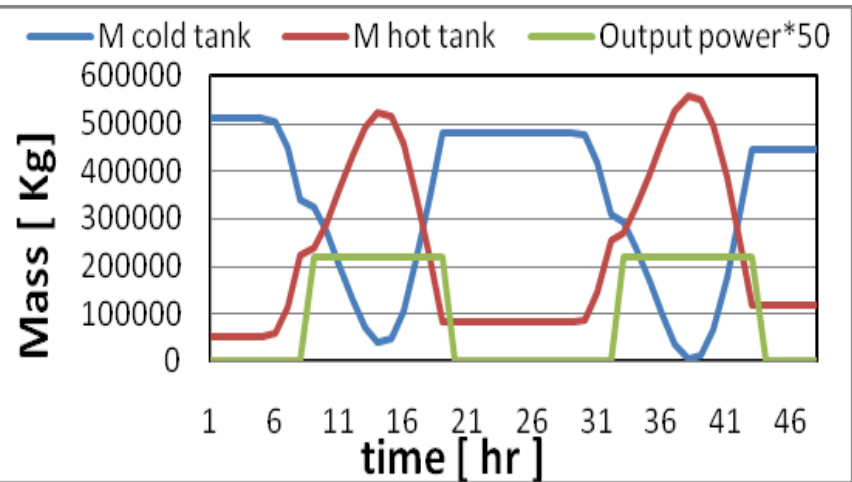

Figure (10) the behaviour of mass of hot and cold tank and the electrical power generation during $23^{\text {th }}, 24^{\text {th }}$ march for MPS10 in Aswan ( $45.8 \%$ capacity factor)

\section{FEASIBILITY STUDY OF MPS10 IN ASWAN}

PS10 in Spain was built in December 2005 and opened in March 2007. The total Cost is $(\$ 47 \mathrm{M})$, the specific cost is about $4200 \$ / \mathrm{kWgross}$. In order to calculate the capital cost of the MPS10 for Spain and Aswan in 2013, the inflation rates are taken from 2007 to 2013 [18, 19, 20, 21, and 22]. The total calculated cost of the PS10 for Spain and Aswan in 2013 is $(\$ 50.6 \mathrm{M})$, the specific cost is about $4600 \$ / \mathrm{kWgross}$. Figure (11) show the total cost of the plant with increasing capacity factor of the MPS10 plant. 


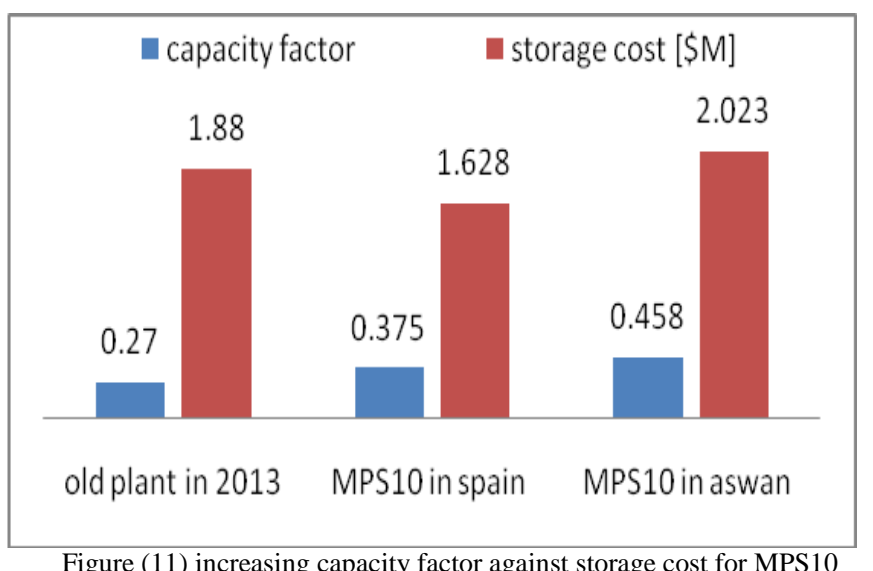

Figure (11) increasing capacity factor against storage cost for MPS10

The landing cost of the MPS10 (\$1M) is ignored in Toshka, Aswan due to the governmental support for encourages national energy project on desert lands. The indirect cost $(\$ 8.6 \mathrm{M})$ also is reduced in Toshka, Aswan due to the relatively low cost of labour and transportation. In Europe, about $(\$ 2.2 \mathrm{M})$ of the capital cost yearly goes for operating and labours. In Aswan, the yearly operating and labour cost is reduced by $75 \%$ (equal about $0.5 \mathrm{M} \$$ /year).

\section{CONCLUSIONS}

The main conclusions come out of this work are summarized as follow:

- The PS10 plant in Spain is used as a demonstrative model in order to estimate the relative advantage of installing a modified storage one in Toshka, Aswan.

- PS10 with two tanks molten salts thermal energy storage system (MPS10) in Spain increasing the capacity of the existing PS10 by (25MWh) daily.

- The daily capacity of MPS10 in Aswan (110MWh) is higher than the capacity of the MPS10 in Spain (90MWh).

- The capital cost of MPS10 in Spain (\$50.348M) is less than the capital cost of the existing PS10 in Spain $(\$ 50.6 \mathrm{M})$. And the Storage cost of MPS10 in Spain $(\$ 1.628 \mathrm{M})$ lowers than the storage cost of MPS10 in Aswan (\$2.023M).

- The feasibility study shows that installing MPS10 in Toshka saving about (\$7.9M) labour and indirect cost. And helping for accommodate the life in it.

\section{NOMENCLATURE}

CST: Concentrated Solar Tower.

Cp: Specific Heat at constant Pressure

(2660 J/Kg.k for solar salt).

DSG: Direct Saturated steam Generation.

M: Mass of tank $(\mathrm{Kg})$.

$\dot{\mathrm{m}}_{\mathrm{tr}}$ : Tower flow rate $(\mathrm{Kg} / \mathrm{s})$.

$\dot{\mathrm{m}}_{\text {tur: }}$ : Steam generator flow rate $(\mathrm{Kg} / \mathrm{s})$.

$\mathrm{Q}_{\mathrm{sg}}$ : Steam generator power $\left(\mathrm{Watt} / \mathrm{m}^{2}\right)$.
$\mathrm{Q}_{\mathrm{tr}}$ : Tower Receiver Irradiation $\left(\mathrm{Watt} / \mathrm{m}^{2}\right)$.

$\mathrm{T}_{\mathrm{tr}, \mathrm{o}}$ : Tower outlet temperature.

$\mathrm{T}_{\text {tr, in }}$ : Tower inlet temperature.

$\mathrm{T}_{\mathrm{h}, \text { in }}$ : Hot tank input temperature.

$\mathrm{T}_{\mathrm{h}, \mathrm{o}}$ : Hot tank outlet temperature.

$\mathrm{T}_{\text {tur,o }}$ : Steam generator outlet temperature.

$\mathrm{T}_{\text {tur,in }}$ : Steam generator inlet temperature.

$\mathrm{T}_{\mathrm{c}, \text { in }}$ : Cold tank inlet temperature.

$\mathrm{T}_{\mathrm{c}, \mathrm{o}}$ : Cold tank outlet temperature.

$\mathrm{U}$ : Overall heat transfer coefficient.

$\mathrm{V}$ : Tank Volume $\left(\mathrm{m}^{3}\right)$.

$\mathrm{dM} / \mathrm{dt}$ : Change of the tank mass.

$\mathrm{dE} / \mathrm{dt}$ : Change of tank total energy.

$\eta_{\text {th }}$ : Thermal efficiency of Rankine cycle (45\%).

$\eta_{\mathrm{tr}}$ : Tower receiver efficiency $(90 \%)$.

$\rho$ : Density of heat transfer fluid

$\left(1870 \mathrm{Kg} / \mathrm{m}^{3}\right)$ for solar salt.

\section{REFERENCES}

[1] PS10: a 11.0 MW Solar Tower Power Plant with Saturated Steam Receiver, 2005. Available from :< http://www.upcomillas.es/catedras/crm/report05/Comunicacion es/Mesa\%20IV/D\%20Valerio\%20Fern\%C3\%A1ndez\%20\%20Solucar\%202.pdf>.

[2] Battleson, K.W.(1981), "Solar Power Tower Design Guide: Solar Thermal Central Receiver Power Systems, A Source of Electricity and/or Process Heat," Sandia National Labs Report SAND81-8005, April.

[3] Duffe J. A., Beckman, W. A., Solar Engineering of Thermal Processes. Wiley 2006.

[4] Tamme R., et al, 2002. Innovative thermal energy storage technology for parabolic trough concentration solar power plants. Bologna, Proceedings Euro Sun at the 4th ISES Solar Congress.

[5] J. E. Pacheco, S. Showalter, W. Kolb, "Development of a Molten Salt Thermocline Thermal Storage System for Parabolic Trough Plants", Solar Forum 2001, Washington DC, April 2001.

[6] Final Technical progress report available at http://ec.europa.eu/energy/renewables/solar_electricity/doc/200 6_ps10.pdf.

[7] Torresol Energy Investments, S.A., 2011. Connected to the sun - Gema solar Brochure. [Online] Available at: http://www.torresolenergy.com/EPORTAL_DOCS/GENERAL/ SENERV2/DOC-cw4e88b3bb57c8f/folleto-gemasolar.pdf. [Accessed 16 March 2012].

[8] Annual Report 2001 of PSA, 2001. Available from: http://www.psa.es/webeng/techrep/2001/atr2001eng.pdf.

[9] Zalba B., et al., 2003. Review on thermal energy storage with phase change: materials, heat transfer analysis and applications. Applied Thermal Energy, Volume 23, pp. 251-283.

[10] Herrmann U., et al, 2002. Overview on thermal storage systems. Workshop on Thermal Storage for Trough Power Plants. [Online] Available at: http://www.nrel.gov/csp/troughnet/pdfs/uh_storage_overview_ ws030320.pdf. [Accessed 20 March 2012].

[11] Herrmann U., et al, 2004. Two-tank molten salt storage for parabolic trough solar power plants. Energy, 29(5-6), pp. 883893.

[12] D. Kearney, B. Kelly, R. Cable, N. Potrovitza, U. Herrmann, P. Nava, R. Mahoney, J. Pacheco, D. Blake, H. Price, "Engineering Aspects of a Molten Salt Heat Transfer Fluid in a Trough Solar Field", Proceedings of 11th Solar Paces 
International Symposium on Concentrating Solar Power and Chemical Energy Technologies, Zurich, Switzerland, September 2002.

[13] Hermann, Ulf, Kearney D., "Survey of Thermal Energy Storage for Parabolic Trough Power Plants," Journal of Solar Energy Engineering, Vol. 124, pp145-152.

[14] Sohal M.S., et al, 2010. Engineering Database of Liquid Salt Thermophysical and Thermochemical Properties, Idaho Falls, Idaho: Idaho National Laboratory.

[15] Ingham J., et al., 2000. Chemical Engineering Dynamics. In: 2. edition, ed. Modelling with PC Simulation. s.l.:Wiley-VHC, pp. 33-35.

[16] Nexant Inc., "USA Trough Initiative: Nitrate Salt HTF Rankine Cycle, Steam Generator, and Thermal Storage Analyses", prepared for NREL, March 2001.

[17] NJ - CHP, 2012. NJ Combined Heat and Power. [Online] Available at: http://njchp.rutgers.edu/files/Steam_Turbines.pdf
[Accessed 17 May 2012].

[18] W. Zhang, "Concentrating Solar Power" - State of the Art, Cost Analysis and Pre-Feasibility Study for the Implementation in China, Universit?t Stuttgart, Institut für Energiewirtschaft und Rationelle Energieanwendung.

[19] Solar Advisor Model (SAM), 2006, National Renewable energy Laboratory, Golden CO.

[20] Jim Hinkley et al, Concentrating solar power - drivers and opportunities for cost-competitive electricity, available at < http://www.csrio.au.

[21] M. A. Mustafa, "Analytical Study of an Innovated Solar Power Tower (PS10) in Aswan", International Journal of Energy Engineering, Vol. 2, pp273-278, 2012.

[22] Euro Stat Website available from http://epp.eurostat.ec.europa.eu/portal/page/portal/eurostat/hom e. 